\title{
Anti-Semitica at Ohio State University
}

\author{
By GEORGE P. SCHOYER
}

The OHio State University LibraRy has recently purchased a valuable collection of books on anti-semitism. Most of the material deals with or has reference to French anti-semitism, though there are some items dealing with other countries. The 251 items in this collection range in date from 1841 to the present. There is material on pre-World War I French anti-semitism, as well as material on antisemitism during the post-World War I decades and the German occupation of France during World War II. This short article will attempt to indicate a few of the important items which are representative of the type of material to be found in this collection.

An early example of French anti-semitism is Alphone Toussenel, Les Juifs, rois de l' époque (Paris, 1845). This is one of the first French anti-semitic books of modern times. It represents the views of a former Fourier socialist, nature writer, and hater of urban life. It expressed the views of a rural anti-semitism and was probably the most influential anti-semitic book published in France before the writings of Edouard Drumont. Drumont, the leading pre-World War I antisemitic journalist in France, is represented in this collection by many books. Of special interest is an enlarged edition of his most notorious work, La France Juivre (Paris, 1885), which contains many illustrations derogatory to Jewish life. There are many other examples of Drumont's anti-Jewish works in this collection, as well as several books about him. An example of a book favorable to him is George Bernanos' La Grand peur des bien-pensants (Paris, 1931). This work is an admiring biography of Drumont by a famous French stylist and sometime member of the Action Française. Charles
Mr. Schoyer is a staff member in the history and political science library, Ohio State University.

Renault's L' Israelite Edouard Drumont (Paris, 1896) is an attack on Drumont for not being, strangely enough, sufficiently anti-semitic.

Leon Daudet, the very influential writer for the Action Française is represented in this collection by $A u$ Temps de Judas (Paris, 1933), which is an account of the period $1890-1900$ and is full of bitter attacks on many of the leading personalities of the period. Another interesting book dealing with the same period is Philippe Sapin's L'Indicateur Israelite (Lyon, 1897), which listed all Jewish families in France, town by town. It was apparently written for a pogrom that never took place.

The collection contains many editions in several languages of the hoax known as the Protocols of the Wise Men of Zion. The Protocols were largely based on Maurice Joly's Dialogue aux enfers entre Machiavel et Montesquieu (Brussels, 1868). This book, also part of the collection, is a satire on Napoleon III's government, originally written in 1865 . The parallels between it and the Protocols are, however, so close that a large part of the Protocols must have been derived from Joly's book. Albert Asseo in Dialogues sur les temps nouveaux (Paris, 1937) shows that the Protocols were indeed forged from Joly's book by two Russian officers, one of whom, Gen. Ratchkovsky, was the head of the Russian Secret Police in Paris at the time Joly's book was published. As a footnote to this discussion, Asseo's book was fatal to its author, who was searched out and deported by the Nazis after the fall of 
France. John Gwyer's Portraits of Mean Men: A Short History of the Protocols of the Elders of Zion (London, 1938) is a complete history of the Protocols and their forgery.

There are several volumes in the collection which were published just prior to or during the German occupation of France. Examples of these works are L. F. Celine's rabid Bagatelles pour une massacre (Paris, 1938) and his equally violent $L$ ' École des Cadaures (Paris, 1948), a book that may have suggested the idea of death camps to Hitler. There are also two examples of French collaborationist radio addresses during the German occupation, Philippe Henriott's, Ici, Radio-France (Paris, 1943), and Jean Hérold-Pacquis' L' Angleterre comme Carthage (Paris, 1944). Johannes Oesterreicher, Racisme, antisemitism, antichristianism (Paris, 1940) was the last antianti-semitic book published in France before the Nazi invasion. This book is quite rare since the Nazis destroyed most of the copies.

Still another volume that listed Jewish families and was used against them was the Weimarer Historische-Genealoges Taschenbuch (Munich, 1913). It is an anti-semitic directory for pogrom purposes of all leading Jewish families not only in Germany but throughout the rest of Europe as well. In spite of its early publication date, the Nazis apparently used it to round up squads for death camps. Its detailed tracings of Jewish families and their ancestors, as well as anyone else in any way related to Judaism, make this work one of the most terrible books ever published.

These are some of the interesting works in this collection of anti-semitica, and there are many others equally as valuable. There are many books illustrated with anti-Jewish cartoons and jokes, most of them repulsive. The student of French and European social history should find this a valuable collection.

\section{MALC . . .}

(Continued from page 334)

tious, personable optimism. His audience retired for the evening reinforced in its belief that all old architecture is not bad nor is all new architecture good.

Saturday was spent at St. Louis University some thirty blocks due east of WU through beautiful Forest Park. Two large discussions occupied the morning hours. The first, led by Donald Oehlerts of Colorado State University, concerned "Centralized Processing for College Libraries," a topic which he was well prepared to present, having recently completed a study of opportunities for interinstitutional library cooperation in his home state. The second was guided by Daniel P. Bergen of St. Benedict's College, Kansas, and was designated "Col-

lege Environment and the College Library." Many of Mr. Bergen's pregnant and provocative ideas may be gleaned from one paper which he published in this journal in November and another which appears in the present issue. At noon ACRL Executive Secretary Joseph Reason spoke to lunching conferees at the Coronado Hotel on "Experiences of an American Librarian in Burma," where he had spent 1961/62 for the Association and the Ford Foundation.

A note must be made of the weather. It was the finest kind of spring in St. Louis on April 5-6, and it appeared that everything that could bloom during the two days did so. MALC has not always been so fortunate.-D.K. 